\title{
Mõistatused ja mõistatamine Virumaal
}

\begin{abstract}
Piret Voolaid
Teesid: Käesolevas uurimuses on vaatluse all aegade jooksul Virumaa kihelkondadest kirja pandud mõistatused kogu liigilises mitmekesisuses. Artiklis analüüsin nii vana (klassikalist) kui ka uuemat kihistust, sh kasutuskonteksti ja funktsiooni muutusi, kasutajaskonda. Lisaks mõistatustekstide vormi- ja sisutasandi dünaamikale on paralleelselt tähelepanu all žanri sotsiaalsed funktsioonid, mida peegeldavad arhiivimaterjali hulgas leiduvad vähesed kasutuskontekstide üleskirjutused. Virumaa teated kinnitavad üldisemat tendentsi, et taluühiskonnas lisaks meelelahutuslikule funktsioonile maagilist ja usundilist tähtsust omanud žanris prevaleerivad tänapäeval meelelahutuslikud funktsioonid. Kirjutises osutan mõistatuste kui rahvaluuleliigi erinevatele, kohati vastuolulistele eesmärkidele.
\end{abstract}

Märksõnad: huumor, keerdküsimused, liitsõnamängud, mõistatused, mõistatuste funktsioonid, mõistatuste liigispetsiifika, rituaalsus, Virumaa folkloor

Varasemad Virumaa kihelkondadest kirja pandud mõistatustekstid (nt 19. sajandi lõpu ja 20. sajandi alguse Jakob Hurda ja Matthias Johann Eiseni rahvaluulekogudes) on enamasti küsimus-vastus-vormis ülesehitusega klassikalised mõistatused (ehk traditsioonilised ehk tavalised ehk pärismõistatused). Oma olemuselt on need mingi objekti, olendi, eseme, tegevuse vm nähtuse sõnalised, mõistukõnelised kirjeldused, mis kajastavad valdavalt talueluga seotud mõisteid, etnograafilist miljööd, koduloomi, loodust. Alates 20. sajandi lõpukümnenditest kogu Eestis, aga ka Virumaal kogutud mõistatusaines kinnitab, et klassikaliste mõistatuste osakaal on tänapäeva elavas folkloorses kasutuses peaaegu olematu. Kuigi levinumaid neist (nt sibula kohta Seest siiruviiruline, pealt kullakarvaline ja kapsa kohta Lipp lipi peal, lapp lapi peal ilma nõela pistmata) tuntakse väga hästi, on see siiski valdavalt lasteaias või koolis omandatud raamatutarkus. 
Nüüdisajal on aga esiplaanile tõusnud mõistatuste hilistekkelisemad alaliigid, nagu näiteks keerd( nalja)küsimused ehk konkreetse küsisõnaga algavad otseküsimused, nt Miks koer saba liputab? - Sellepärast, et saba koera ei liputa; liitsõnamängud (enamasti algusvormeliga missugune? või milline?, vastuseks ei nõuta mitte omadussõna, vaid liitnimisõna, nt Millised konnad ei krooksu? - Ülikonnad), piltmõistatused (küsimuspooleks visuaalne kujutis, vastuseks pildi kirjeldus, nt Mis on pildil? - Karu ronib puu otsa), lühendiparoodiad: (küsimuspooleks üldtuntud lühend (üldjuhul suurtähtedest koosnev akronüüm) ja vastuseks tavapärasest järsult erinev vaimukas ja humoristlik, tihti poliitilise ja/või seksuaalse varjundiga lahtiseletus, nt Mis on ENSV? Eesti naiste sukavabrik). Esitamise juures pole neis esiplaanil mitte vastajalt õige vastuse saamine, kus rääkija justkui esitab kuulajale küsimuse, vaid teiselt vastust eeldamata vastatakse oma küsimusele pärast lühikest pausi ise. Sedalaadi mõistatused on enamasti orienteeritud koomikale, väljendades ühtlasi ka sotsiaalset kriitikat. Eesti keerdküsimuste humoriseerumise või anekdoodistumise protsessi alguseks võib pidada nõukogude perioodi, mil ühiskondlikke tabuteemasid (poliitika, erootika) kajastati läbi huumori.

\section{Mõistatamise sotsiaalsed funktsioonid Virumaa teadete põhjal}

Mõistatuste dialoogiline vorm seab selle pärimusliigi olulisele kohale kommunikatsiooniprotsessis. Suulises traditsioonis ei kujuta ettegi mõistatuste esitamist ilma vähemalt kahe osapooleta - küsija ja vastajata. Ka kirjalikul kujul, nt paberajakirjanduses, internetikülgedel või sotsiaalmeedia postitusena on mõistatused suhtlussõnumi rollis. Mõistatusi kui mõttetööga seotud nuputamist nõudvat kõnežanrit on vaadeldud nalja ja meelelahutuse sotsiaalsetes seostes, kui “jäälõhkujat” pingelistes suhtlussituatsioonides, kui erootilise õhustiku loojat ja võimendajat. Samas võib mõistatustele omane mitmetähenduslikkus olla niivõrd kultuurile orienteeritud, et jääb väljasseisjale suletud raamatuks (Kaivola-Bregenhøj 1996: 14), kuid mängib olulist rolli asjaosaliste sotsialiseerumisprotsessis (McDowell 1979: 223-226; Abrahams 1968: 155 jpt) ja väljendab ritualiseeritud ühtekuuluvust. Suhtlemist hõlbustav funktsioon on mõistatustel ka nüüdisaegses mardi- ja kadrisantide repertuaaris. Tänapäeva linnade magalarajoonide kadri-ja mardisandid on tavaliselt pererahvale võõrad ning neile võõral territooriumil aitavad mõistatused neutraalteemana murda nii külaliste kui ka pererahva ebaleva oleku.

Mõistatamine ja suhtlus on tihedasti seotud, ometi ei olda tavaliselt võrdsetel positsioonidel: küsija on vastaja ees eelisolukorras, sest tema teab oma 
küsimusele õiget vastust. Vastaja saab küsijaga võrdsele platvormile tõusta ainult oodatud õige vastuse äraarvamisega. Mõistatuste abiga määratletakse sageli ka suhtluskonna hierarhilised positsioonid, vastuse äraarvajale langeb osaks võitja-au ja kaaslaste lugupidamine.

19. sajandi lõpuveerandil ja hiljem kogutud üsna vähesed ja juhuslikud teated eesti mõistatuste kasutustavade, tüüpiliste mõistatamissituatsioonide jms kohta näitavad, et mõistatuste varasem sotsiaalne ja kultuuriline taust on olnud laiahaardeline: nende kasutajaskond pole piirdunud lastega ja nende funktsioon pole olnud pelgalt meelelahutuslik, vaid seotud laiema maailmapildiga. Talurahva töökalendris on mõistatused kuulunud sügistalvisesse perioodi, mil rehetöö ja linatöötluse lõpulejõudmisega mindi üle talvistele tubastele töödele, naispere ühistele tööõhtutele, mehed aga siirdusid raie- ja veotöödele (Hiiemäe 1994: 5). Lõppenud põllumehe-karjakasvataja majandusaasta andis mahti seda pühitseda ja hea seista järgmise aasta saagi edenemise eest. Richard Viidalepp (2004: 45-54, 70) on osutanud, et sügistalvisel videvikuajal jutustamisega on põhjarannikul kaasnenud mõistatuste mõistatamine. Siin on kinnituseks Gustav Vilbaste üleskirjutus:

Ka on vanemal ajal ja ka nü̈̈d hiljemal ajalgi, mõnes kohas, 1. novembrist, "pühimieste päiväst” Mardipäevani iseäralisi "jäguõhtuid” peetud. Neil jäguõhtutel ei ole tööd tehtud, vaid käidud perest peresse, aetud "vanaviisi jutte" ja antud "muistatuksi". Kes mõistatuste andmises ehk nende äramõistatamises osav olnud, sellest peetud palju lugu. (EÜS VIII $1244<$ Kuusalu khk (1911).)

Samalaadne teade pärineb ka Mall Proodelilt (Hiiemäelt) Kadrinast:

Ennem õhtati mõistatati. Meie ema mõistatas meile. Isekeskis ka. Siis sai raamatust ja üheteise käest ka. Talvel ikke rohkem - kui sai kedratud ja käsitööd tehtud. Käisivad veel külainimesedki videvikul. "Videvikku viida ja koitu kiida,” öeldi ikka. Eesti aja lõpul jäi vähemaks juba. (RKM II 251, 271 (10) < Kadrina khk, Metsameeste k (1969))

1936. aastal kirjutab Vaivarast Ludmilla Kraavik: Mõistatati õhtuti kokku tulles ja pühadel. Mindi "videvikule" naabrite juure, kui ei tahetud tuld põlema panna ja kedrata. (ERA II 125, 473 (77)).

Mõistatamine maagilise toiminguna pidi tagama edu uuel aastal. Nõnda taotleti, et loomad sigiksid, et söök laual oleks, et "söögilusikad ära ei kaoks". Lusikad tähendavad siin kujundlikus mõttes toitu, nagu selgitab Lüganuselt 1960. aastast pärit üleskirjutus lusikad pidid kaduma ja selle kommentaar: Kui nälg tuleb, siis lusikku ei õle vajagi, tähendab sedä. (RKM II 201, 41/2 (55).) 
Õige vastuse arvamine polnud alati igaühele jõukohane, seda kunsti valdasid vaid targemad. Ka uudsus on alati inimesi paelunud: kes millegi uuega välja tuleb, seegi on suhtlusprotsessis ülejäänutest vaimult kõrgemal.

Vanemad inimised andasivad mõistatusi lastele. Sie õli asjamies, kenel tõine õhta jällä mõni uus mõistatus õli. Lapsed siis päiväl jällä pladisesivad oma moistatusi omasugustele. (ERA II 292, 188 (76) < Jõhvi khk, Kohtla k - Endel Mets (1940).)

Kui tänapäeval on mõistatamine ealiselt laste pärusmaa, siis veel 20. sajandi algul ei olnud vanus mõistatamisel oluline; esineb küllalt teateid mõistatamise kui vägagi mehise tegevuse kohta, mistõttu võib mõistatamist pidada ka tänapäeva mõttespordiharrastajate mälumängude ja viktoriinide omaaegseks eelkäijaks.

\section{Mõistatamine kui põlualune tegevus}

Kui ühelt poolt oli talurahval justkui kohustus mõistatada, et ikka toit laual ja karjaõnne oleks, siis teisalt on mõistatused olnud üleskirjutuste põhjal ka taunitud nähtus. Mõistatamist on peetud patuseks tegevuseks ja seostatud kurjade jõududega, nagu ilmneb näiteks Tõnu Wiedemanni 1892. aasta kirjapanekust:

Enne vanaste tiu aeges, kui öösetel rehtesid sai pekstud, siis on ühes kohas tiumehed ja vaimud üheteisele mõistatusi üles and, nii kui sie endisel ajal meie esivanematel viisiks oli, kui nad juba küll üks hiaste ja teine viel paremaste olid mõistatand, siis on üks punane käsi tuld läbi lae nähtavale ja häel on öeld: “Mõista, mõista, mis sie on?” Selle piale põle enam kiegi julgend kõvaste hingatagi. (H II 37, 677 (1) < Jõhvi.)

Sedasorti "verise käe” motiivid moodustavad õieti üsna selge muistenditüübi, milles on kokku liitunud uskumus ja seda "kinnitav" hoiatusjutt.

Mõistatamise kui mingitel puhkudel keelatud ja põlualuse tegevuse kohta annavad tunnistust paarkümmend jutukirjapanekut, mis olemuselt on klassikalised oudusjutud. Kuivõrd tunnusmotiiviks on siin mingi reegli/tabu rikkumine (laps astub keelatud kohale, ostab keelatud asja), kurja inimese (asja) ootamatu majjailmumine või majas oleva eseme kurjaks muutumine (Kõiva 1996: 169), sobituvad alljärgneva stereotüüpse süžeeskeemiga tekstid sellesse žanrisse imehästi. Lihtsustatud kujul on selliste kirjapanekute sisuskeem järgmine. Õhtul pimedas tares esitatakse üksteisele mõistatusi, kui ühtäkki pistetakse aknast või uksest sisse verine käsi, loomapea vmt ja võõras hääl hüüab: "Mõista, mõista, mis see on?" Nimetatud tunnustest on juttudes täidetud nii 
reeglirikkumine (mõistatamiskeelust üleastumine) kui ka kurja jõu kehastuse ootamatu majjailmumine. Lugude õpetlikkus väljendub nende kulminatsioonis, nii nagu on kirjeldanud M. J. Eisenile Otto Hintzenberg:

Näärilaupääva ôhtal kogunud noored poisid ja tüdrukud ühte peresse kokku. Valanud seal õnne ja teinud muud nalja. Viimaks toodud õled tuppa ja kõik istunud õlede peale ja hakanud mõistatusi üheteisele üles arvata andma. Viimaks läinud kaks poissi õue. Näinud, et üks suur kollase näuga vanamoor seisnud õue peal, suured pikad hambad nagu reha pulgad suus. "Mõista, mis see on?” hü̈̈dnud vanamoor läbi hammaste, ja kadunud ise ära. Poisid tulnud hirmuga tuppa ja rääkinud seda lugu teistele. Mõistatamise lust kadunud poistel, tüdrukutel kohe ära. (E 6249/59 < Tapa.)

Et põhiliseks rahvajuttude jutustamise ja mõistatuste esitamise ajaks oli sügistalvine videviku- ja jaguaeg, siis loovad pimedad ôhtud selliste õudusjuttude vestmiseks sobivaima õhustiku. Pealegi on jutusüžee ise neilsamadel aegadel harrastatud mõistatamistegevusega tihedasti seotud, mis lisab veelgi põnevust. Aeg ja koht on neis juttudes küll piiritletud (pime õhtu talutares), kuid juttude tõepärasust kahandab tõsiasi, et sarnaselt muinasjutu algusvormeliga on kasutusel umbmäärane "ükskord".

Vähemalt paikkonniti võib kiriku teeneks pidada rahva suhtumist, mille kohaselt on mõistatamist peetud patuseks tegevuseks, mis võis häirida nt laulusalmide päheõppimist.

Laupäevast mõistatamiskeeldu põhjendab ja sellele järgnevat karistust kuradi ilmumist - kirjeldab 1939. aastal elavalt ka Kadrinast pärit A. Lauk:

Kui ma veel veikene olin, siis see oli meil moodist, lastel, kui vanemad inimesed olid läind karjalauta, siis lapsed istusid nurgas ja ajasid juttu. Aga ainult laubä õhta, siis ei tohtind vanaviisi jutte mitte rääkida, siis käidi saunas ja saunast tulles akkasid vanad inimesed piiblit lugema. Lapsed pidid kõik vagaselt pealt kuulama, aga kui kunagi vallatust täis, pugesid salaja vana rehetuppa. No nü̈̈d akkame mõistatama, ega isa ja ema ei tea. Siis akkasid mõistatama. Küsinud ikka üksteiselt mõistatusi. Ühekorraga kargab üks must mees ja keksleb põrandal ja karjub: "Mõista, mõista, mis mina olen!” Tal olid sarved peas, pikk suur saba taga ja obuse kabjad all. Siis olid lapsed kõik ehmatanud ja jooksid tuppa tagasi, rääkisid vanematele ja saivad noomida ja läksid nuttes magama ja lubasid, et nad ilmaski enam laubä õhta ei mõistata. (ERA II 240, 551/2 (3).)

Mõistatuste kui millegi sageli sobimatu ja alaväärse tegevuse kohta annavad tunnistust kindlat tüüpi arhiiviteated. Selleteemalistest üleskirjutustest kumab 
läbi halvustav suhtumine mõistatustesse ja nende esitamisse. Mõistatamine tundub nende kirjapanekute järgi otsustades olevat justkui meedium maapealse reaalsuse ja üleloomulike saatanlike jõudude vahel, tööriist, millega võib välja kutsuda kurja vaimuilma tegelased, nt vanapagana. Sarnase suhtumisega teateid on 1969. aastal Rakverest üles kirjutanud folklorist Pille Kippar:

Mõistatused pidand vanapaganast olema. Kui mõistatatud, siis vanapagan käind öösi ümber toa, et kus minu raamat on ja kus minu raamat on. Mis te mu raamatuga möllasite, et siis enam ei tohtind mõistatada. (KKI 49, 229/30 (23).)

Üleloomulikud tegelaskujud seesugustes teadetes on nt vanapagan, paharet, kollase näoga vanamoor, vana sarvik, tondid, rehepapp. Mõnes variandis tuleb ette loom, nt punastlauku hobuse pea, verine vasikas, mis viitavad ilmselt seosele kuradiga.

\section{Mõistatuse mitteteadjale ettenähtud karistus}

On teateid, et kehv mõistataja omandas lihtsalt tobukese maine, kuid talle võis osaks saada ka karistusi. Mõistatuste seesugustele sotsiaalsetele funktsioonidele osutavad mitmesugused mõistatamismängud, millest arhailise usundilise taustaga on nt soomlastel tuntud dramaatiline "Hymyläs käimine" (hölmölän matka - 'reis kilplasse'1), kus taipamatu vastaja saadeti kalevalamõõduliste värsside saatel õige vastuse järele Hölmölässe, Hyvölässe, Himolasse, Huikkolasse, Hymylässe (Virtanen 1977: 36). Mäng seisnes selles, et vastaja, kes teatud arvu mõistatusi ära ei arvanud, sai teiste pilkealuseks ja saadeti värsside saatel kusagile kaugemale n-ö vastuste järele. Eestis on kõnealuse toimingu kohta nappe teateid Virumaalt, Lõuna-Tartumaalt ja Võrumaalt. ${ }^{2}$ Virumaalt Kadrinast pärineb Johannes Sõsteri 1910. aastal saadetud teade, mille järgi see, kes mõistatuse vastust öelda ei suutnud, lähetati Üikülla, Armilda Halliku üleskirjutuse põhjal Uikkalasse:

Ennemast ôli mõistatamise mood. Kui kaks-kolm inimest tulid kokku, hakati mõistatama. Kes seitse mõistatust ei mõistnud ära mõista, sie aeti uikkala:

Uih, aih, uikkala, pani jala ukse konksu piale, sittus viis vaadi täit.

Kes ei mõistnud mõistatada, sie piab selle ära sööma. (ERA II 166, 241 (17) < Iisaku khk (1937).) 
Võib üsna kindlalt arvata, et uikkala näol on tegemist Ida-Virumaal asuva väikese küla Uikalaga. Soome mõistatusmänguga võib ilmselt paralleele tõmmata, sest nii Üiküla kui Uikkala Eesti kohanimedena tunduvad olevat soome laenud (vrd sarnase kõlaga soome Huikkola). Mõistatuste vastamisel jännijäänu saatmine kusagile õigete vastuste järele on lisanud esitussituatsioonile mängulisust ja rituaalsust. Saatmisel kasutati pikki algriimilisi vormeleid ja (ilmselt siis otse "sündmuskohal" ettemaalitud) fantaasiaid sellest, mis taipamatuga juhtuma hakkab. Paik (Uikala, Rasina jne) muutub siin justkui mingiks äraspidiseks "teiseks ilmaks". Soome etnomusikoloog Timo Leisiö (2000: 273-283) on vaadelnud selle arhailise nähtuse ajaloolist levikut üle kogu Soome, määratlenud selle kuulumise šamanistliku praktika juurde ja leidnud, et hilisem mõistatusmäng on välja kasvanud tõsiseltvõetavast rituaalist. Hymylä jt kohanimed on selles mängus algselt sümboliseerinud äraspidist allmaailma/teispoolsust, kuhu šamaan läks üleloomuliku väe abil oma kogukonna (siinpoolsuse) jaoks tarvilike vastuste järele (samas: 284).

\section{Mõistatamise roll kosja- ja pulmakombestikus}

Kui mõistatusele vale vastuse andmine ka päris eluga jumalagajättu ei tähendanud, siis enese saatust sai õige või väära vastusega suunata küll. Seesugust funktsiooni iseloomustab mõistatuste andmise ja vastamise roll kosjakombestikus, mille kohta annavad kinnitust mitmed Virumaalt pärit teated. Vastumeelse kosilase olevat noorikueas neiu vanemad keeruka mõistatusega nagu mitmes muinasjutuski perest eemale tõrjunud, näiteks alljärgnevas Mall Proodeli saadetud teates:

Kui noormees tuli kosja, anti talle neiu vanemate poolt mõistatus lahendada. Mõistatas ta õigesti, oli ka kosjaskäik õnnestunud; kui ta aga "kimpu jäi” ja seega oma rumalust näitas, ei võetud kosjasid vastu ning kosilane katsus õnne mõnes teises majas. Meelepärasele kosilasele esitanud neiu vanemad lihtsama mõistatuse. Kas seda käesoleval sajandil siinkandis kasutatud on, pole täpselt teada, aga 19. saj. lõpul oli ta veel laialt levinud, seletab Pouliine Kiiver. (RKM II 61, 55 < Iisaku khk, Metsküla (1956).)

Mõistatamine oli pulmakombestikus veimevaka jagamise osaks, kus leidis aset kingituste tõotamine noorikule pärast andide jagamist (Tedre 1973: 87). Folklorist Ülo Tedre järgi polevatki tegelikkuses ennemuiste pulmakinke tehtud, välja arvatud nooriku kaasavara ja vaderite annetused (samas: 88). Kinkijad olid eeskätt omaksed ja sugulased, lubadused lausa mõistukõnelised ja humoristlikud. Jakob Hurda rahvaluulekorrespondendi Annette Raidi 1895. aasta 
kirjapaneku järgi kinkis nt Haljala khk nadu noorikule pulma ajal selle lamba, mis seitse korda nädalas niidetakse ja sellest peab veel saama villad ämmale, rauad minile, s.o põrand pühkida ja pühked ämmale, aga luud minile; küdi kinkis pruudile tuule laeva ja seitse sülda siidinööri, s.o kätki ja mähke pael; nadu kinkis pruudile vedruvankri ja vedrudega kätki, aga aasta pärast jääb kuivaks ammeks, kui ema kodunt ää lääb, s.o ema süle ja käed, peiupoiss pruudile kaksteistkümmend paari härgi, kes kõik ühekorraga kündma hakkavad, s.o kaksteistkümmend paari vähki (H III 23, 106 (47-50).) jne.

Pulma pruukidest Haljalas annab ülevaate järgmine Danel Pruhli kirjapanek M. J. Eisenile 1894. aastast:

Kui annid jägatud ja raha panemine ja lõppetusele sai, siis isamees hakas noore paarile kinki tellima. Sest kaks pesaehitajad lindu on, kellele meie peaksime aitama pesa ehitada jne. Kes siis tahtis kinkida, see läks ja ütles oma lubatuse ära, ja selle eest sai jälle ôlut ehk viina antud, ja ka õnnistatud. Kink ei saanud mitte otsekohe sõnatega välja ööltud, vaid ikka mõistumoodi, nii kui kätki kinkija ütles: kingin laeva; mesipuu tündritäis kärbasid; lapse nartsud - tosin ehk pool salvrätikud; kana, kes tagurpidi tööd teeb - lapse müts, paljas pea ei ole ilus näha; lapse kuub - veike laps on kuuega ilusam. Varss, kellega esimene poeg kiriku sõidab. Vasikas, kellest lüpsja ehk kündja saab. Lammas, kellel neli kord aastas peab kuue seljast ära võtma jne. Mõni ütles ka: kingin lamba, kingin lehma ehk kingin vankri, mõni noor mees ka: kingin noore paarile pulmad ehk "pulmad tagasi”. Nenda kinkisid suurem jagu pulmalisi üht ja teist ja igaüks otsis oma kingile parajaid sõnu, kuda naljakam, seda parem. (E 5167.)

\section{Nüüdisaegne mõistatusrepertuaar kui rahvahuumor}

Üht osa traditsioonilisi mõistatusi ei tunta tänapäeval paljuski seetõttu, et endisaegse taluelu igapäevaste toimingutega seotud tarbeesemed (sh tööriistad, mahutid), põlluharimise, rõivaste ja toiduvalmistamise viisid on kadunud kasutusest ning ühtlasi neid märkivad sõnad igapäevasest keelest. Ka nõukogudeaegse olmega seotud keerdküsimused ja lühenditõlgendused on elavast käibest juba kadunud, sest teema pole enam aktuaalne. Tänapäeva mõistatusaines on väga tugevate rahvusvaheliste mõjustustega ning seotud kultuuriliste, poliitiliste ja majanduslike muutustega, mida põhjustab massikommunikatsiooni tehnoloogia kiire areng ning inimeste ja kaupade suurenenud mobiilsus. Neid mõistatusi iseloomustab temaatiline mitmekesisus, nad on enamasti orienteeritud koomikale ja naljale. 


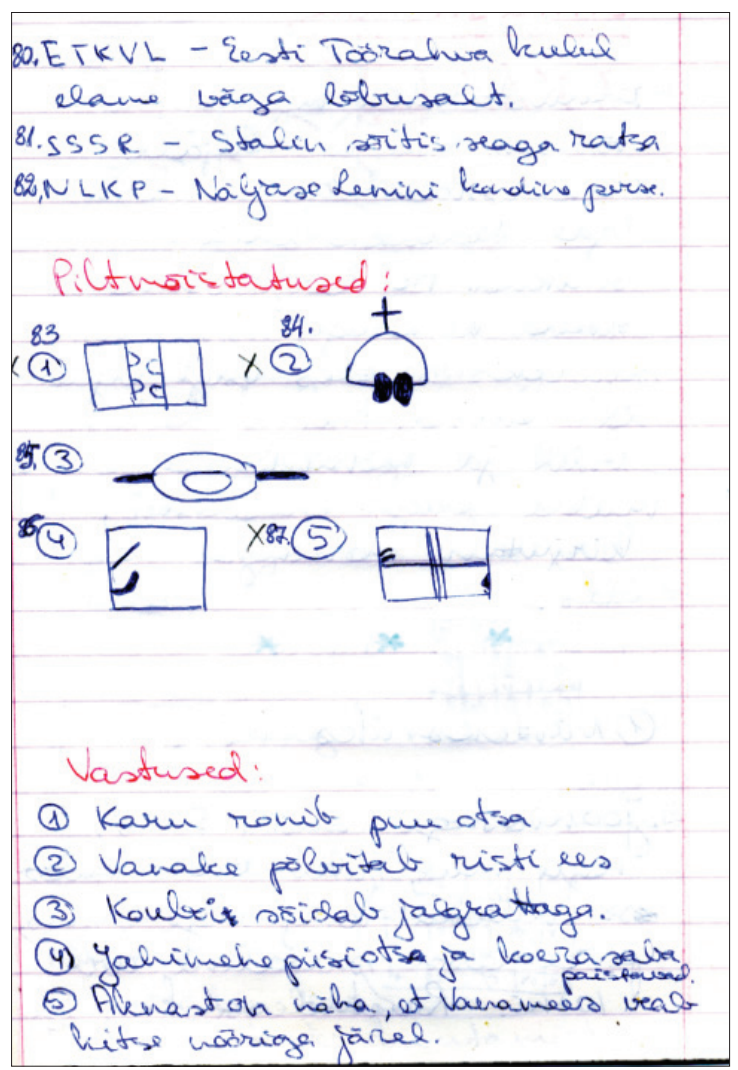

Joonis 1. Narva Eesti Keskkooli 9. kl õpilase Teele Partsi saadetud lühenditõlgendused ja piltmõistatused, 1992. a. (RKM, KP 2, 244).

Ka uuem Virumaa materjal näitab neid suundumusi. Mall Proodel on 1956. aastal oma kodukandist Iisaku kihelkonnast pannud kirja 300 mõistatust, saadetises on ka küsisõnaga algavaid vanemaid keerdküsimusi: Kas võtad üle aia hüppaja või läbi aia läikija? Hundi või kitse; Miks jookseb jänes üle mäe? Mäe alt ei pääse; Millal saab sõelaga vett kanda? Kui vesi on jääs jne (RKM II 61, 33-54).

Mõistatusžanri politiseerumise ja humoriseerumise protsessi algusajaks võib pidada nõukogude aega, algul venelaenuliste, nn Armeenia raadio küsimuste massilise leviku aega. Emil Draitseri (1998: 21) järgi said põhiliselt poliitilisi, etnilisi ja erootilisi teemasid käsitlevad Armeenia raadio küsimused Venemaal populaarseks 1950. aastatel, Stalini-järgsel sulaperioodil. Raadioga, mis oli tugeva tsensuuri all, samuti Armeeniaga, polnud neil küsimustel õieti midagi 
ühist, oma nime said nad traditsiooniliste armeenia mõistatuste vormi järgi, mis olid venelaste hulgas populaarsed 1940.-1950. aastatel. Absurdsete küsimuste ja täiesti ettearvamatu vastusega armeenia mõistatuste valvenäiteks toob E. Draitser keerdküsimuse, mida tuntakse meilgi:

Mis on roheline, ripub laes ja piiksub? - ? - Heeringas. - Miks roheline? Minu heeringas, võin ta ükskõik milliseks värvida. - Aga miks ta laes ripub? - Minu heeringas, võin ta ükskõik kuhu riputada. - Aga miks ta piiksub? - Selle üle olen isegi imestunud. (Draitser 1998: 21)

Mõistatuste allžanreist kohandusid totalitaarse režiimi vastastele teemadele enim keerdküsimused ja lühendid (vt ka Voolaid 2009). Poliitiliste naljade sattumine trükiallikaisse oli tsensuuri tõttu välistatud, ent kirjalikul kujul levisid need nt kladedes. Tänapäeva koolipärimuse kogumisvõistlustest võttis osa kaks Virumaa kooli: Narva Eesti Keskkoolist laekus 1391 lk vastuseid 69 õpilaselt, Iisaku Keskkoolist 812 lk 43 õpilaselt. 1992. aasta oli viimane aeg koguda nõukogude aja folkloori, nii leidub ka mõlema Virumaa kooli saadetises Armeenia raadio küsimusi, nagu nt Armeenia raadio käest küsiti kord, kas lakke saab sülitada. Armeenia raadio vastas: Ei saa, sest et laest tulevad kõik meie viisaastakuplaanid (RKM, KP 2, 603 (12)), Miks on abieluvoodil kolm kohta? Lenin on alati meiega (RKM, KP 7, 782 (10)), Miks kaevatakse tihti Tallinna tänavaid? Otsitakse Kalevipoja parteipileti lisalehti (RKM, KP 7, 783 (13)) jpt. Tänu 1992. aasta koolipärimuse kogumisele jõudis arhiivi ka hulganisti piltmõistatusi, mille laiem levik algas Eestis 1960. aastatel ja saavutas populaarsuse kõrgaja 1980. aastatel (vt ka Hiiemäe 1995).

2007. aasta võistlusele laekus kaastöid Virumaalt rohkemgi, osalesid Väike-Maarja Gümnaasium (130 õpilast), Iisaku Gümnaasium (52 opilast), IdaVirumaa Kutsehariduskeskus (7 õpilast), Tamsalu Gümnaasium (42 õpilast), Vinni-Pajusti Gümnaasium (22 õpilast), Jõhvi Gümnaasium (1 õpilane), Tapa Gümnaasium (1 õpilane). 1990. aastate lõpus ilmus küsimus-vastus-vormilistesse naljadesse uus rahvusvaheline tegelaskuju blondiin, kes on vaieldamatult lemmiktegelane ka 2007. aasta Virumaa õpilastöödes, nt Väike-Maarja Gümnaasiumi vastustes:

Miks blondiin ja elevant ei tööta arvuti taga? - Sest nad kardavad hiirt; Miks blondiin ei sõida KIAga? - Sest ta telefoni peal on kirjas "NOKIA"; Miks blondiin naerab, kui välku lööb? - Sellepärast, et ta arvab, et teda pildistatakse; Miks blondiin viskab kella aknast alla? - Sellepärast, et ta tahab näha, kuidas aeg lendab. (EFA, KP 26, 29 (2E).)

Blondiini rumalust naeruvääristavad naljaküsimused võivad olla ühelt poolt vastulöögiks tavalisele inimesele kättesaamatu iluideaali vastu ja teiselt poolt 


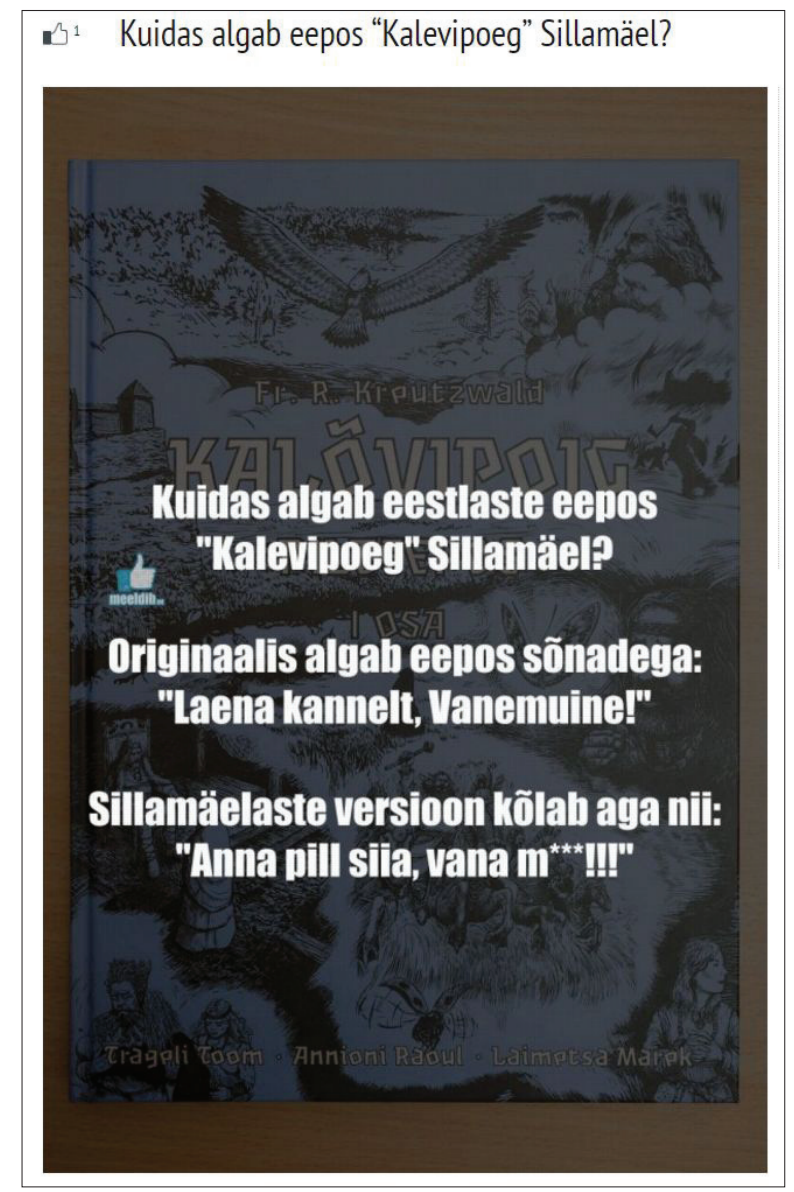

Joonis 2. Nü̈̈disaegsetes internetimeemides kui ühes visuaalset ja verbaalset teksti kombineerivas huumorivormis kasutatakse väga sageli küsimuse ja vastuse vormis naljaküsimusi. http: / / meeldib.postimees.ee /2015 / 07/ kuidasalgab-eepos-kalevipoeg-sillamael/\# http:/ / meeldib.postimees.ee/2015/07/ kuidas-algab-eepos-kalevipoeg-sillamael/\#_.

kompenseerida meeste ja naiste võrdõiguslikkuse poole püüdlevas ühiskonnas valitsevat soorollide kadumist. Blondiin võib oma juhmust näidata kõikvõimalikes elusituatsioonides. Üks väljanaermiseks sobivamaid valdkondi on tänapäeva tehnoloogia, mis näib blondiinile tõesti üle jõu käivat ja võib samas sümboliseerida tavainimese hirmu keeruka tehnika ees.

Virumaa paigadki on jõudnud mõistatustesse. Adra kohta on mõistatus Narva koer kükakille? (EM 1401). Tuhat-tuhat, sada-sada lääva niitsest silda mööda rauatsede Narva? Herneid pandaks patta (EM 2255). 
Eesti keerdküsimuste andmebaasis (Voolaid 2004a) on järgmised naljaküsimused: Mis on Tartus väike ja Rakveres suur? R-täht. (EFA II 19, 76 (1)) ja Mis on Virus suur ja Moskvas väike? V-täht. (RKM, KP 20, 340 (5)). Liitsõnamängude andmebaasis (Voolaid 2003) leidub tekst Missugune raibe kasvab põllul? Rakvere raibe. (RKM I 2, 265 (7) < 1956). Lühendinaljade hulgast (Voolaid 2004b) leiame Ida-Virumaal asuva SOMPA humoorika venekeelse tõlgenduse: Samoe opasnoe mesto posle Ameriki (RKM II 465, 64 $(37)<1994)$. Mitmes 1992. aasta koolipärimuse kogumisvõistluse vastuses toodud lühenditõlgenduses on inspiratsiooni pakkunud Narva: LKNÜ (Leninlik Kommunistlik Noorsooühing) - Lenin kutsus Narva üles (RKM, KP 20, 286 (7)), NBA (National Basketball) - Narva brigadiride aktsiaselts (RKM, KP 14, 312 (7)), NSVL (Nõukogude Sotsialistlike Vabariikide Liit) - Narva silla vallutasid lambad (RKM, KP 21, 53 (10)). Huvipakkuv on seegi, et ühtegi neist lühenditõlgendustest pole saatnud Virumaa kooliõpilased.

Dialoogivormi ja lühiduse poolest sobivad mõistatused žanrina efemeerseteks kiirnaljadeks, rahvapäraste vaatekohtade manifesteerimiseks. Tänapäeva infotehnoloogia ajastul, interneti ja osalusmeedia tingimustes on märgata sõnaliste keerdküsimuste üha massilisemat illustreerimise ja visualiseerimise suundumust. On tekkinud keerdküsimuste uued meemilised, multimodaalsed ja -meedialised esitusviisid, mida iseloomustavad nt kirjalikkus, digitaalsus, omamoodi rahvavisualiseerimine. Naljaküsimused võivad sündida ja levida meediapõhjalise uudisfolkloorina, millega reageeritakse nt päevakajalistele (poliitilistele, olmelistele vmt) reaalelu sündmustele. Rikkaliku meemiainese hulgas võivad mõnikord ette tulla ka Virumaa paikkonnad. Näitena võib tuua järgmise meemi (joonis 2), millel on rahvuseepose "Kalevipoeg" kaanepildil keerdküsimus Kuidas algab eestlaste eepos "Kalevipoeg” Sillamäel? Originaalis algab eepos sõnadega: "Laena kannelt, Vanemuine!” Sillamäelaste versioon kõlab aga nii: "Anna pill siia, vana m...!!!” on Eesti dominantkultuuri positsioonilt vihje erinevustele Ida-Virumaa etniliste rühmade vahel, nimelt elab eestlasi Sillamäel stabiilselt alla 5\% (Sillamäe 2014).

\section{Varasemad suuremad Virumaa mõistatuste kogud}

Varasema mõistatusainese ehk klassikaliste mõistatuste kohta saab esitada täpse arhiivistatistika. Arvo Krikmanni ja Jaak Krikmanni koostatud andmebaasi "Eesti mõistatused" (Krikmann ja Krikmann 2012) põhjal on Virumaalt kirja pandud ühtekokku 7785 klassikalist mõistatust 831 tüübist (vt joonis 3). Mõistatuste kogumisloo on põhjalikult läbi kirjutanud Rein Saukas (2005a, 2005b, 2007), siinkohal väärivad nimetamist aktiivsemad kogujad Virumaal. 


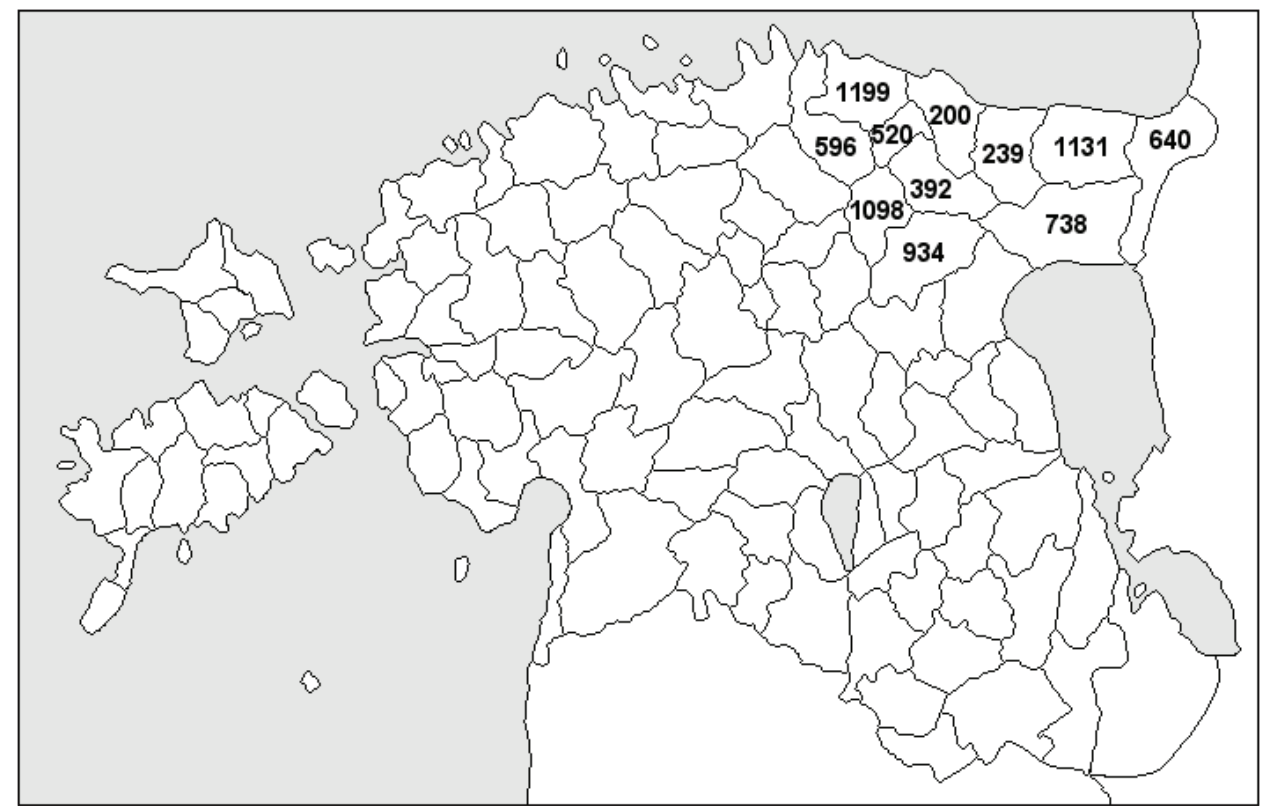

Joonis 3. Virumaalt on kirja pandud kokku 7785 klassikalist mõistatust 831 tüübist. Enim (1199 mõistatust) on kirja pandud Haljala kihelkonnast, pingereas järgnevad 1131 ülekirjutusega Jõhvi ja 1098 üleskirjutusega Väike-Maarja kihelkond. Kaardil ei kajastu 1 Alutaguse ja 97 Virumaa mõistatust, millel kihelkond täpselt määramata.

Umbkaudu 30 Jakob Hurda korrespondenti on lähetanud aastatel 1888-1893 silmapaistva hulga mõistatusi. 545 mõistatust on saatnud Vaivara kihelkonnakooli õpetaja Heinrich Masing (vt joonis 4), kooliõpetaja Jaan Tammemägi on 1893. aastal saatnud Vaivarast 195 mõistatust. Kooliõpetaja ja põllumees Julius Aleksander Reepärg on aastatel 1889-1895 Haljala kandist kirja pannud 242 mõistatust, kooliõpetaja ja pärastine jutukirjanik ning kodu-uurija August Tõnurist on aastail 1889-1891 Jõhvi ja Vaivara piirkonnast kogunud 228 mõistatust, Paulus Paurmann (kooliõpetaja, mõisavalitseja ja põllumees) on aastatel 1889-1891 Jõhvi kihelkonnast saatnud 208 mõistatust, Anna Elken Väike-Maarjast 1890. aastal 179 mõistatust, kihelkonnakooli õpilane Emilie Ellert 1889. aastal Iisakust 109 mõistatust.

Matthias Johann Eiseni kogus pole Virumaalt kirja pandud mõistatuste hulk kuigi esinduslik. Üle 100 mõistatuse on Eisenile kirja pannud nt Kadrina kooliõpetaja ja pärastine kunstnik Alfred Konstantin Kivi (113 mõistatust), Juhan Lilienbach Rakvere kihelkonnast (106 mõistatust) Narva Kreenholmi vabriku töötaja ja ajalehtede kirjasaatja Johan Landsman (102 mõistatust, kirjutas üles vabrikus kaastöötajatelt kuuldut), Mihkel Jürna Lüganuselt ja Viru-Jaagupist (102 mõistatust). 


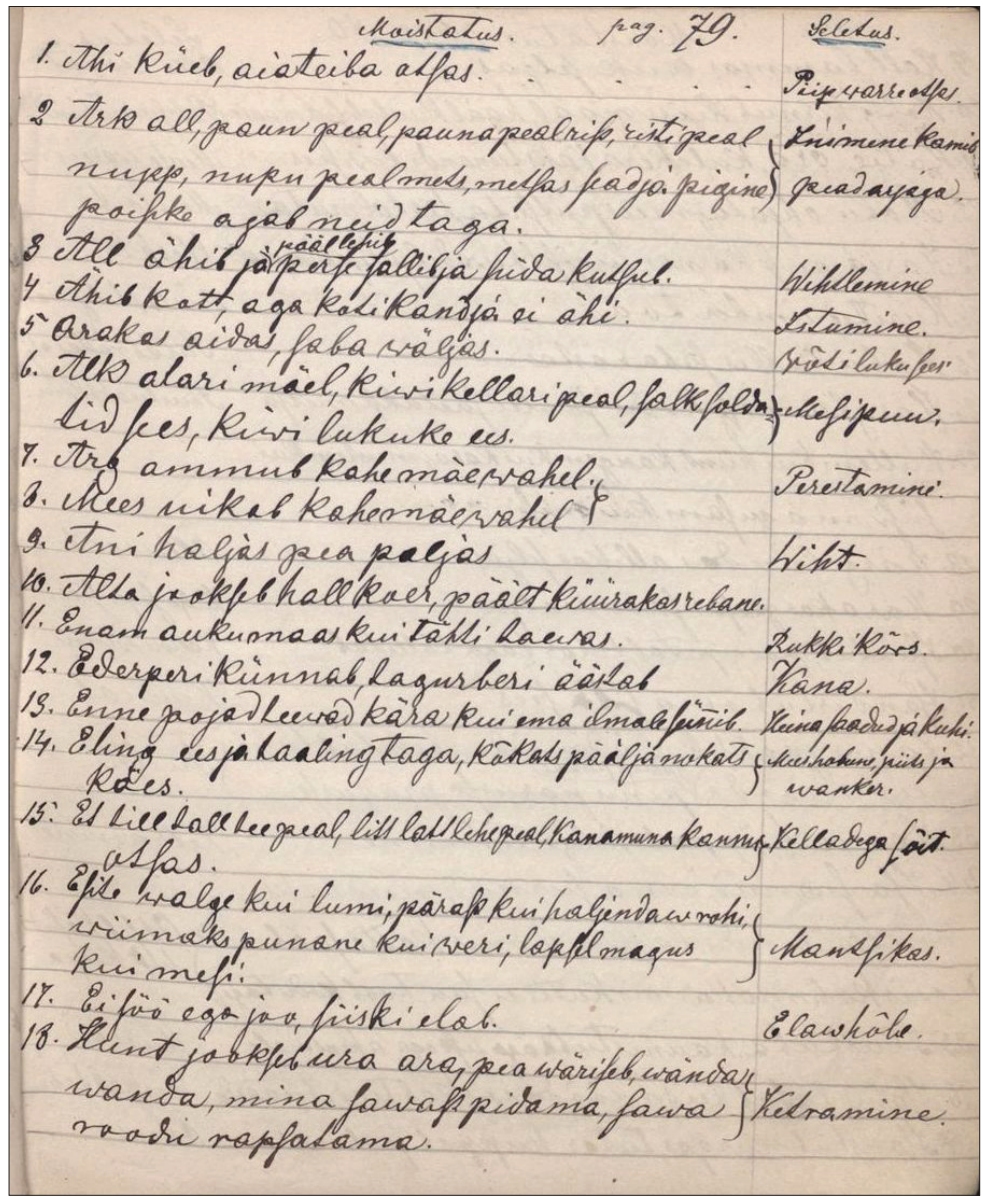

Joonis 4. Lehekülg Vaivara kihelkonnakooli õpetaja Heinrich Masingu mõistatuste saadetisest Jakob Hurdale, 1889. a. (H II 7, 79 (1-18)).

\section{Ainsa üleskirjutusega klassikaliste mõistatuste tüübid}

Allpool on ära toodud eesti mõistatuste akadeemilises väljaandes (EM I-II) leiduvad mõistatused (kokku on tüüpe 2800), mis on esindatud kõigest ühe-kahe üleskirjutusega ja ainult Virumaal. Näited pärinevad varasematest mõistatuste saadetistest. Tähelepanelikul lugemisel võib märgata osa tekstide juures vulgaarset alatooni, mõnedki neist on kahemõttelise küsimuse ja "süütu" tähendusega mõistatused, kus küsimuspoolde on meelega mitmemõtteline kujund sisse kootud. Üldjuhul on mõistatused üles ehitatud nii, et küsimuse kujund 
peaks vastajat õige lahenduse leidmisel abistama, kuid selliste kahemõtteliste mõistatuste eesmärk on nimme suunata vastaja eksiteele. Lahendus on samas vägagi süütu. Siin avaldub taas üks mõistatuste ja mõistatamise funktsioone: selliste siht pole olnud mitte niivõrd see, et õige vastus ära arvataks, kuivõrd see, et õnnestuks (eriti naissoost) adressaat segadusse ajada ja erootilist pinget tõsta, eelkõige muidugi noorte seltskondades (vt ka Krikmann 2000).

\section{Vaivara kihelkonnast (Vai)}

Ikka seisab naistel ees, lihast kui näeb tema sees, ümarik on tema pragu, karvad katvad tema nägu? Muhv (1893).

Jänis jookseb jäädä mööda, timba-tamba teeda mööda? Lumi sadab (1893 ja 1889).

Keereldi-kaareldi, mülla-mälla möllaja? Veski (1887).

Minu ragu, sinu ragu, puu ragu, pinu ragu? Tuisk (1893).

Nurr-narr nurka, pirr-parr parsile, nõgelasi varsile, läheb puu pragoje? Lumi sadab (1893).

Vanapagan tantsib, vänt ei puudu maha? Vänt (vokil) (1893).

\section{Jõhvi kihelkonnast (Jõh)}

Ema läheb ees, ei saa suhu ega selga, tüter läheb taga, saab suhu ja selga? Vokk (1889).

Hõbeõhjad, vaskvaljad, seest siidine, päält pärline? Lõõtsapill, härmoonik (1889).

Mado mättäs, nenä välläs? Lapse nenä nattas (1889).

Must härg, mugulad sarved, läheb järvejäe pääle, pistab sarved sisse lopsti? Aidavõtti (1889).

Punane peegel seina peal? Päike (1888).

Päiväl pilgub, öösel pilgub, pilkasel pimedal pilgub? Aken (1890).

Risu rikkama tua ees? Hauriit (1888 ja 1891).

Siibita lennab ja jaluta võttab kinni? Aed võttab lumesao kinni (1888).

Suvel pea sinetab, talvel kuulab kuuse all? Vene (1888). 
Tôlk-tõlk üle küla? Pesupesemine kurikaga (1888).

Vett täis, vett täis, põle prunti ies, sõisab püsti, sõisab püsti, põle konti sies? Kanamuna; kurk (1939).

\section{Iisaku kihelkonnast (Iis)}

Kiigal-kaagal, viigal-vaagal? Viiul (1888).

Kuulub, kui raiutakse, ei kuulu, kui maha langeb? Lambaniitmine (1939).

Nirr-narr nurka, pirr-parr parsile, kanepine köis ja kadakane laud, niinepuune nui, nuial kaks vart? Kass (1889).

Perse äärest, perse seest, lakub perset? Singiliha, kanamuna, härjakeel (1939).

Tutmed-rutmed ratsi naise puusa peal? Lambavill (1889).

\section{Lüganuse kihelkonnast (Lüg)}

Ies on hiire itemet, keskel kella korinat, taka taari naka? Kaljaasti (1948).

Neli kitse kusevad ühte aukuje? Lehmä lüpsamaie (1889).

\section{Viru-Nigula kihelkonnast (VNg)}

Kirju lehma, keikud sarved, konnib järvejäe peal, jäe paukub ja veri väriseb? Laev (1892).

Üks peab ja kaks veab? Künnimees härgadega (1889).

\section{Haljala kihelkonnast (Hlj)}

Isasta visasta karvane pugust, persesta kuus küinart karvane? Kasukas (1888-1902).

Kaks neitsid ühe kuldse karbi sees? Läätsed kauna sees (Dateerimata).

Kargut, karguti all koogid, kookide all renn, renni all tõnn, tõnni sees jahud? Käsikivid (1895).

Mees läheb metsa, õenes puu õlal? Kütt (Dateerimata). 
Mõista, mõista muu truu, pane peäle poe truu, päele need kili-kolinad, päele nuppu kuldakella? Söömalaud, leib, lusikad, vaagen (1897).

Mõista, mõista mõnne sõrme, läbi kätte känne sõrme, sõsteri lehed sõrisesid, vasteri lehed varisesid? (1893, lahendus puudub).

Mõista, mõista mõõdu, pane peale paadu, keskelle kelevere, peale nuppu kullakeele? Pudru kausis, või silmas, lusikas silma peal (1889).

Pihkane pääl ja harjane all? Päähari (1933).

Pisikene pimbulaine, ranna raku kuerukene, las nemad võidu vupsitavad, kaksipidi kraksutavad: puu puhtaks, lauad lagedaks? Lähkrikivid (1891).

Seitse selga seljakute, kaheksa kaela kaelakute, üheksa üle õlade? Paja ahel (1889).

Soldat on minu suur sõber, laisk on minu söömalaud, virk, kes mind ära tapab? Täi (1888-1902).

Suu neljanurgeline, keel kaheksakandiline? Loomakell (1892ja 1888-1902).

Suvel sööb, talvel situb? Heinaladu (1888).

Tõrs tuua võeralt maalt, siin maal vitsutata? Kübar, siin maal pannakse pael peale (1888).

Vasksed vesiväravad ja kuldsed kusilauad? Naisterahva asi (1888).

Veikene mees, punane kasukas seljas? Vähk (1893).

Vesi all ja vesi peal, kala ujub siiski kuivalt läbi? Kangakudumine (1888).

Vägi läheb välja, peremehe peial jäeb püsti? Lamba sittumine (1888-1902).

Üks on pikk ja piiramata, teine lai ja noolemata, kolmas kaljusta kõvera? Jõgi, meri, oja (1892).

\section{Kadrina kihelkonnast (Kad)}

Isa Tiiu, ema Tiiu, tütar Tiiu, tütretütar ka veel Tiiu? Männipuu (1888).

Ise igerik ja agerik, läheb põllule, tagumik paljas, näitab põesale p[erse]t? Kana (1966).

Mõista, mõista mõlle-rõlle, kilgutivad kõlle-rõlle, perenaise parajad riistad, nahka nad niblivad-nablivad? Lambaniit (1930). 
Pisikene pilla-palla, lühikene lülla-lalla, kõige parem perenaine? Kulp (1896).

Pukk-pugadi, lakk-lagadi? Tuuleveski (1897).

Tuas peksetakse reie, lademed tualael? Suits (1888).

Vana naene, valged reied? Õuekamber ehk riideaet (1896).

Üks oinas, kaks kotti? Nahkkasukas kahe ripptaskuga (1968).

Üks seljali maas, seitse segavad sees? Leemekauss ja lusikad (1897).

\section{Rakvere kihelkonnast (Rak)}

Kihelkonna kaljaasti? Veeämber (1892).

Mees mauli maas, naine selili seljas, kõht körti täis? Leivaküna (1888).

Neli auku niidikeras? Lehma udar (1892).

Viht vitsata, luud lehita, tort takuta? Habe (1888).

\section{Rakvere linnast (Rkv)}

Ups-tups tuuakse, üle välja viiakse, saba sõlme lüüakse, rihmad kinni siutakse? Kanga ülespanemine puude peale (1965).

\section{Väike-Maarja kihelkonnast (VMr)}

Ei ole suuri-suur ega tilli-tilluke, siiski pikem kui jõgi, aga madalam kui regi? Tee (1887).

Hall kukk, punane hari? Maja põleb (1888).

Ilustaja ihu sees? Kõrvarõngas (1888).

Kere ümber sarved, sarvede peal võru? Vankriratas (1888).

Kui külge puudutad, siis kummardab, kui mööda lähed, siis ei liigutagi? Kaevuvinn (1888).

Kui torkab, siis näitab, kui ei torka, siis ei näita? Tule põlema panemine (1888 ja 1890). 
Mees läheb metsa, vesi ees, sild taga? Ämblik (1965).

Must mees, kalasaba taga? Pääsuke (1890).

Mõõgast pikem, nurgast kõveram, teeb mitme elule otsa? Vikat (1888).

Neitsid tantsivad, punane poisike vahel? Keel ja hambad (1895).

Neli hiirt jooksevad ühte auku? Lüpsmine (1939).

Päält sinine, seest valge? Suhkrupää (1887 ja 1888).

Pisukene riist, aga palju varandust mahub sisse? Rahakott (1888).

Punane põld, valge kari? Suu ja hambad (1890).

Puutööd teeb, ise sest sööb? Rähn (1888).

Sees sisiseb, peal pisiseb, kui välja saab, siis kõrvetab? Pajaaur (1890).

Seest siid, pealt samet? Pada (1888 ja 1890).

Vedel vedela vihamees? Tuli ja vesi (1888).

Õues sepp, tuas sepp, tagakambris on tôllassepp? Linamasin (1890).

Ühe ema lapsed, teineteist ei tunne? Jäljed (1889).

Üks passel, sada lappi? Kapsas (1939).

\section{Viru-Jaagupi kihelkonnast (VJg)}

Ees elgutimed, taga telgutimed, kaks kanget kahelpool? Härja-ikes (pärast 1879).

Must kui süsi, süsi ei ole, tuhnib kui siga, siga ei ole, karvad ta kannab ning sile ei ole? Mutt on must kui mustem süsi (pärast 1879).

Odrane orikas, sarapuune sitaauk? Lähker (1889).

Puhib ja ähib, aga paigast ei pääse? Sepalõets (1889).

\section{Simuna kihelkonnast (Sim)}

Pisikene poisikene, piip oli suus, pamp oli seljas, ise laulis saksa keeli: Kibuvitsa Villem surnd? Kell (1938 ja 1953). 


\section{Narvast (Nrv)}

Härja vaev lehma reite vahel? Lehma piim udaras (1893).

Mees läheb metsa, oad peas? Loomal sarved peas (1904).

\section{Virumaa esindatusega mõistatustüübid}

Ahi küdeb teiba otsas? Piip (Vai, Jõh).

Ait alleri mäel, kivikelleri peal, saksa soldatid sees, puulukk ees? Linnuрuu (Vai, Iis, Jõh, Sim, Nrv).

Ema ees, tühe kõht, tütar taga, täis kõht? Voki (Vai, Kuu, Jõh).

Harakas sabadelekse, saba pista pistelekse, moorile munad munetakse, munad mulle annetakse? Ahjuluud, leivalabidas ja leivad ahjus (VNg, $\mathrm{Hlj})$.

Hele täht, tume täht, rikka mihe maja külles? Aken (Rak, Hlj, Koe).

\section{Kokkuvõtteks}

Virumaa mõistatusainese diakrooniline analüüs näitab, et vormiliselt on klassikaliste mõistatuste taandudes tõusnud elujõuliste alaliikidena esile keerdküsimused, liitsõnamängud, piltmõistatused, lühendmõistatused. See suundumus langeb kokku kogu Eesti mõistatusainese põhjal ilmnenud tulemustega, mis polegi üllatav.

Klassikaliste mõistatuste hulgas oli põnev jälgida ainult Virumaal ja seejuures kõigest ühe-kahe üleskirjutusega esindatud mõistatustekste, milles on esiplaanil omaaegsed taluargielu terminid, nagu nt tööriistad (nt sepalõõts, käsikivi) ja taluesemed (nt lähker, vankriratas, leivaküna, kaevuvinn). Virumaa kihelkondadest enim esines haruldasi mõistatusi Väike-Maarja (21 teksti) ja Haljala (18 teksti) alal, mis on seletatav ka nende kihelkondade rahvaluuleainese enama esindatusega arhiivis.

Sotsiaalses plaanis võimaldab Virumaalt kirja pandud aines süveneda mõistatuste ja mõistatamise erinevatesse eesmärkidesse. Varasematele usundilistele ja rituaalsetele rollidele viitavad teated, milles mõistatamisel oli kindel koht sügistalvises jutustamistraditsioonis. Maagilisi funktsioone kirjeldavad teated on vastuolulised. Ühelt poolt oli tarve mõistatamisega toidulaua (loomakarja) rikkust soodustada, kosjakombestikus tulevast peigmeest proovile panna või pulmakombestikus veimevaka jagamisel mõistatuste kaudu õnne ja viljakust 
soovida. Teisalt viitavad teated mõistatamisele kui millelegi põlualusele ja patusele ja ilmselt kiriku mõjul on tegevust seostatud kurjade jõududega. Virumaalt pärinevad ka unikaalsed teated omapärasest arhailisi rituaale sisaldavast mõistatamismängust, mille puhul vastuse mitteteadja saadeti Uikalasse kui konkreetsesse paika Ida-Virumaal. Kahemõtteliste mõistatuste taotluseks on olnud innustada noorte seltskondades erootilist meeleolu.

Mõistatuste uuemas ainekihis on esiplaanil meelelahutuslikud sihid ja nali, mille kaudu väljendatakse poliitilisi ühiskondlik-ideoloogilisi suhtumisi ja millega reageeritakse tihtipeale tõsielusündmustele.

\section{Tänuavaldus}

Uurimus on seotud Eesti Teadusagentuuri institutsionaalse uurimisprojektiga IUT 22-5, seda toetas Euroopa Liit Euroopa Regionaalarengu Fondi kaudu (Eesti-uuringute Tippkeskus TK 145 - CEES). Autori eriline tänu kuulub Mall Hiiemäele ja artikli anonüümsetele retsensentidele kõigi asjakohaste märkustesoovituste eest.

\section{Kommentaarid}

1 Soome k hölmöläinen - 1. 'kilplane', 2. 'lollpea, juhmard'.

2 Lõuna-Tartumaal ja Võrumaal oli levinud komme saata mõistatuse mitteteadja vastuse järele Rasinasse. Miks just Rasinasse, see üleskirjutustest ei selgu. Küll on teada, et kõnealune küla on Võnnu kihelkonda kuuluva Mooste valla üks vanemaid, mis Tartu piiskopkonna lääniürikutes esmakordselt mainitud nime all Rassinal (1403). Küla asub kruusateede ristumiskohas, kust lisaks Moostele (Rasinast u $8 \mathrm{~km}$ kaugusel) viivad teed Tartusse (u $40 \mathrm{~km}$ ), Räpinasse (u $18 \mathrm{~km}$ ) ja Ahjale. Rasinasse saatmise kohta on aastatest 1895-1992 ühtekokku 20 teadet. Neist varasemad pärinevad Hurda korrespondentidelt aastast 1888: Neid, kes mõistatuisi ära ei mõista, saadetas Rasina moori manu küüsüma. Võtta kolgits hobeses, uhmer öörikus, pini hand piitsas, kassi hand karpatsis, kats kanapasast karaskit kangli ala ja siis mine Rasinale minemä. Sääl pand vanamoor leiba ahjo ja tüttär näge man tuld, rakkakene villakorvin aho otsa pääl jo nakas haukma. Moor ütlep tütrelle: "Mine kaema, kes tule, rakkakene hauk?” Tüttär lät kaema ja ütles: "Üts tule omma mõistatuse orrega sälan.” Pääle selle tule mõistatuse küsija sisse, tervitap, mis vasta saap võetus, ja nakkap mõistatuisi seletama. (H III 11, 491 < Kanepi khk, Vana-Piigaste v - J. Väggi (1888).) 


\section{Arhiiviallikad}

\section{Eesti Kirjandusmuuseumi Eesti Rahvaluule Arhiivis (järjestatud algusdaatumite järgi)}

H - J. Hurda rahvaluulekogu (1860-1906)

EÜS - Eesti Üliõpilaste Seltsi rahvaluulekogu (1875-1917)

E - M. J. Eiseni rahvaluulekogu (1880-1934)

ERA - Eesti Rahvaluule Arhiivi rahvaluulekogu (1927-1944)

RKM - Kirjandusmuuseumi rahvaluule osakonna rahvaluulekogu (1945-1994)

KKI - Keele ja Kirjanduse Instituudi rahvaluule sektori rahvaluulekogu (1947-1980)

KP - Kirjandusmuuseumi rahvaluule osakonna koolipärimuse kogu (1992-1994 ja 2007)

EFA - Eesti Folkloori Arhiivi rahvaluulekogu (alates 1996)

\section{Kirjandus}

Abrahams, Roger D. 1968. Introductory Remarks to a Rhetorical Theory of Folklore. Journal of American Folklore 81 (320), lk 143-158 (doi: 10.2307/537664).

Draitser, Emil A. 1998. Taking Penguins to the Movies: Ethnic Humor in Russia. Detroit: Wayne State University Press.

EM = Hussar, Anne \& Krikmann, Arvo \& Saukas, Rein \& Voolaid, Piret (koost) 20012002. Eesti mõistatused I-II. Monumenta Estoniae Antiquae IV:1-2. Tartu: Eesti Keele Sihtasutus.

Hiiemäe, Mall 1994. Eesti rahvakalender VI. Tallinn: Eesti Raamat.

Hiiemäe, Mall 1995. Eesti piltmõistatuste loomispõhimõtetest. Kõiva, Mare (toim). Lipitud-lapitud. Tänapäeva folkloorist [I]. Tartu: Eesti TA Eesti Keele Instituut \& Eesti Kirjandusmuuseum, lk 23-32 (http://www.folklore.ee/rl/pubte/ee/cf/lipitud/Eesti\%20 piltmoistatuste.htm - 17. veebruar 2017).

Kaivola-Bregenhøj, Annikki 1996. Riddles and Their Use. Hasan-Rokem, Galit \& Shulman, David (toim). Untying the Knot: On Riddles and Other Enigmatic Modes. New York, Oxford: Oxford University Press, lk 10-36.

Krikmann, Arvo 2000. Lisamaterjali mõistatuste kohta (http://www.folklore.ee/ kriku/ PARINTRO/aenigma.htm - 17. veebruar 2017).

Krikmann, Arvo \& Krikmann, Jaak 2012. Eesti mõistatused. Andmebaas (http://www. folklore.ee/moistatused - 17. veebruar 2017).

Kõiva, Mare 1996. Siis astu aknalauale. Kõiva, Mare (toim). Mängult-päriselt. Tänapäeva folkloorist II. Tartu: Eesti Keele Instituut, lk 166-188 (http://www.folklore.ee/rl/pubte/ ee/cf/mjap/mare.html - 17. veebruar 2017). 
Leisiö, Timo 2000. The riddle game of Visiting Hymylä revisited: A shamanic point of view. Vasenkari, Maria \& Enges, Pasi \& Siikala, Anna-Leena (toim). Telling, Remembering, Interpreting, Guessing: A Festschrift for Prof. Annikki Kaivola-Bregenhøj on her 60th Birthday 1st February 1999. Joensuu: Suomen Kansantietouden Tutkijain Seura, lk 272-286.

McDowell, John Holmes 1979. Children's Riddling. Bloomington, London: Indiana University Press.

Saukas, Rein 2005-2007. Eesti mõistatuste allikalugu I-III. Reetor 5-7. Tartu: Eesti Kirjandusmuuseumi folkloristika osakond, Eesti Kultuuriloo ja Folkloristika Keskus. [I: 2005a; II 2005b; III: 2007.]

Sillamäe 2014 = Sillamäe arvudes 2014: Värskete meretuulte linn. (http://www.sillamae. ee/documents/1122926/3038361/Sillamäe+arvudes+2014.pdf/02ffccc2-8ea7-4dd3-8b01f9287676e9bb - 17. veebruar 2017).

Tedre, Ülo 1973. Eesti pulmad: Lühiülevaade muistsetest kosja-ja pulmakommetest. Tallinn: Eesti Raamat.

Viidalepp, Richard 2004. Eesti rahvajuttude laadist, funktsioonist ja jutustajatest. Sator 4. Tartu (http://www.folklore.ee/rl/pubte/ee/sator/sator4/sator4.pdf - 17. veebruar 2017).

Virtanen, Leea 1977. Arvoitusten esitystilanteet. Virtanen, Leea \& Kaivola-Bregenhøj, Annikki \& Nyman, Aarre (toim). Arvoitukset: Finnish Riddles. Suomalaisen Kirjallisuuden Seuran toimituksia 330. Helsinki: Suomalaisen Kirjallisuuden Seura.

Voolaid, Piret 2002. Eesti piltmõistatused. Tartu: Eesti Kirjandusmuuseum (http://www. folklore.ee/Reebus - 17. veebruar 2017).

Voolaid, Piret 2003. Eesti (liit)sõnamängud. Võrguandmebaas. Tartu: Eesti Kirjandusmuuseum (http://www.folklore.ee/Sonamang - 17. veebruar 2017).

Voolaid, Piret 2004a. Eesti keerdküsimused. Tartu: Eesti Kirjandusmuuseum (http:// www.folklore.ee/Keerdkys - 17. veebruar 2017).

Voolaid, Piret 2004b. Eesti lühendmõistatused. Tartu: Eesti Kirjandusmuuseum (http:// www.folklore.ee/Lyhendid - 17. veebruar 2017).

Voolaid, Piret 2009. Lühendite alternatiivsed tõlgendused - rahvahuumor ja erikeel. Langemets, Margit \& Metslang, Helle \& Sepper, Maria-Maren \& Argus, Reili (toim). Eesti Rakenduslingvistika Ühingu aastaraamat / Estonian papers in applied linguistics 5. Tallinn: Eesti Keele Sihtasutus, lk 345-363 (doi: 10.5128/ERYa5.23).

Piret Voolaid - Eesti Kirjandusmuuseumi folkloristika osakonna vanemteadur, Eestiuuringute Tippkeskuse tegevjuht.

piret@folklore.ee 


\section{Summary}

\section{Guessing and riddles in Virumaa}

\section{Piret Voolaid}

Keywords: compound word games, conundrums, folklore in Virumaa, functions of riddles, humour, riddles, ritualism, specificity of riddles

The article gives an overview of riddles written down in their diversity throughout times in the parishes of Virumaa. The author analyses both the old (classical) and newer layer, including changes in the function and usage context as well as the usership. In addition to the dynamics of form and content layer of riddle texts, attention is parallelly paid to the social functions of the genre, which reflect in the small number of records of usage contexts found in archival materials. Records from Virumaa confirm a more general tendency that the genre which in the peasant society had, besides entertaining functions, also magic and religious importance, today focuses on entertainment.

Piret Voolaid is Senior Research Fellow at the Department of Folkloristics of the Estonian Literary Museum, and Executive Manager of the Centre of Excellence in Estonian Studies.

piret@folklore.ee 